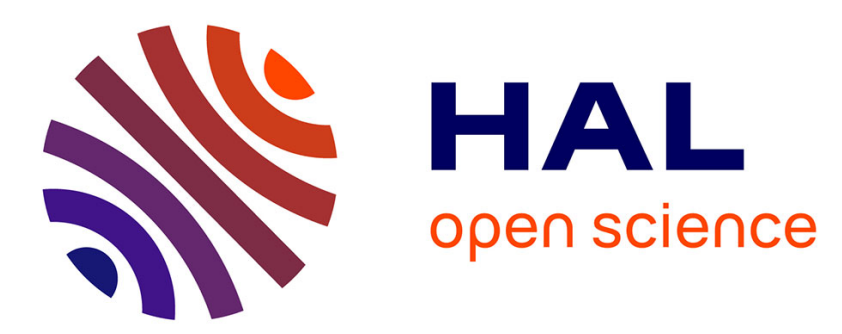

\title{
Down-regulation of the HGF/MET autocrine loop induced by celecoxib and mediated by P-gp in MDR-positive human hepatocellular carcinoma cell line
}

Roberto Mazzanti, Francesca Platini, Consuelo Bottini, Ornella Fantappiè,

Michela Solazzo, Luciana Tessitore

\section{To cite this version:}

Roberto Mazzanti, Francesca Platini, Consuelo Bottini, Ornella Fantappiè, Michela Solazzo, et al.. Down-regulation of the HGF/MET autocrine loop induced by celecoxib and mediated by P-gp in MDR-positive human hepatocellular carcinoma cell line. Biochemical Pharmacology, 2009, 78 (1), pp.21. 10.1016/j.bcp.2009.03.013 . hal-00493506

\section{HAL Id: hal-00493506 https://hal.science/hal-00493506}

Submitted on 19 Jun 2010

HAL is a multi-disciplinary open access archive for the deposit and dissemination of scientific research documents, whether they are published or not. The documents may come from teaching and research institutions in France or abroad, or from public or private research centers.
L'archive ouverte pluridisciplinaire HAL, est destinée au dépôt et à la diffusion de documents scientifiques de niveau recherche, publiés ou non, émanant des établissements d'enseignement et de recherche français ou étrangers, des laboratoires publics ou privés. 


\section{Accepted Manuscript}

Title: Down-regulation of the HGF/MET autocrine loop induced by celecoxib and mediated by P-gp in MDR-positive human hepatocellular carcinoma cell line

Authors: Roberto Mazzanti, Francesca Platini, Consuelo Bottini, Ornella Fantappiè, Michela Solazzo, Luciana

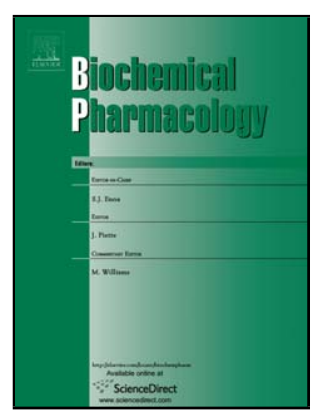

Tessitore

PII:

S0006-2952(09)00189-0

DOI: doi:10.1016/j.bcp.2009.03.013

Reference: BCP 10119

To appear in: $\quad B C P$

Received date: $\quad$ 19-1-2009

Revised date: 10-3-2009

Accepted date: 11-3-2009

Please cite this article as: Mazzanti R, Platini F, Bottini C, Fantappiè O, Solazzo M, Tessitore L, Down-regulation of the HGF/MET autocrine loop induced by celecoxib and mediated by P-gp in MDR-positive human hepatocellular carcinoma cell line, Biochemical Pharmacology (2008), doi:10.1016/j.bcp.2009.03.013

This is a PDF file of an unedited manuscript that has been accepted for publication. As a service to our customers we are providing this early version of the manuscript. The manuscript will undergo copyediting, typesetting, and review of the resulting proof before it is published in its final form. Please note that during the production process errors may be discovered which could affect the content, and all legal disclaimers that apply to the journal pertain. 


\section{Graphical Abstract}

The in vitro pro-autophagic, antiproliferative and pro-apoptotic effect of celecoxib on MDRpositive cells is mediated by the action of P-gp on the HGF/MET autocrine loop.

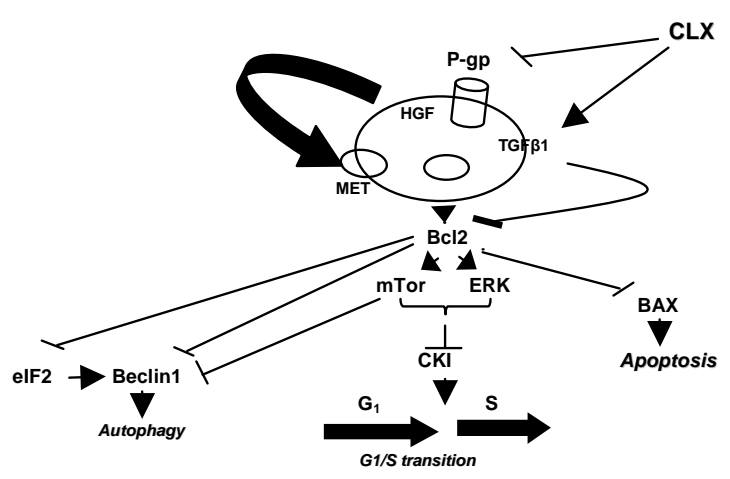


Down-regulation of the HGF/MET autocrine loop induced by celecoxib and mediated by P-gp in MDR-positive human hepatocellular carcinoma cell line.

Roberto Mazzanti ${ }^{1}$, Francesca Platini ${ }^{2}$, Consuelo Bottini ${ }^{2}$, Ornella Fantappiè ${ }^{1}$, Michela Solazzo ${ }^{1}$, and Luciana Tessitore ${ }^{2}$

1. $2^{\text {nd }}$ Medical Oncology of Azienda Ospedaliero-Universitaria Careggi, University of Florence, Istituto Toscano Tumori, Florence, Italy. 2. Department of Food, Chemical, Pharmaceutical and Pharmacological Sciences (DISCAFF), University of East Piedmont “A. Avogadro”, Novara, Italy.

Correspondence to: Prof. Roberto Mazzanti, M.D., $2^{\text {nd }}$ Medical Oncology of Azienda OspedalieroUniversitaria Careggi, Università di Firenze, viale G.B. Morgagni 85, I.50134 Florence, Italy.

Phone: 39-55-4296471; Fax: 39-55-4296468; e-mail: mazzanti-lab@dmi.unifi.it

Running Title: celecoxib-induced autophagy in MDR positive cells. 


\section{ABSTRACT}

Many tumors are resistant to drug-induced cell cycle arrest and apoptosis. We have reported that apoptosis can be restored in human multidrug-resistant (MDR) hepatocellular carcinoma cell lines by celecoxib. Here we show that P-gp mediates cell cycle arrest and autophagy induced by celecoxib in human MDR overexpressing hepatocellular carcinoma cell line by down-regulation of the HGF/MET autocrine loop and Bcl-2 expression. Exposure of cells to a low concentration of celecoxib down-regulated the expression of mTOR and caused G1 arrest and autophagy, while higher concentration triggered apoptosis. Cell growth inhibition and autophagy were associated with up-regulation of the expression of TGF $\beta 1, \mathrm{p} 16^{\mathrm{INK} 4 \mathrm{~b}}, \mathrm{p} 21^{\mathrm{Cip} 1}$ and $\mathrm{p} 27^{\mathrm{Kip} 1}$ and down-regulation of cyclin D1, cyclin E, pRb and E2F. The role of P-glycoprotein expression in resistance of MDR cell clone to cell cycle arrest, autophagy and apoptosis was shown in cells transfected with MDR1 small interfering RNA. These findings demonstrate that the constitutive expression of P-gp is involved in the HGF/MET autocrine loop that leads to increased expression of Bcl-2 and mTor, inhibition of eIF2 $\alpha$ expression, resistance to autophagy/apoptosis and progression in the cell cycle. Since mTor inhibitors have been proposed in treatment of "drug resistant" cancer, these data may help explain the reversing effect of mTor inhibitors.

Keywords: MDR, celecoxib, P-gp, HGF/MET, autophagy 


\section{INTRODUCTION}

Most anticancer therapies kill cancer cells primarily by apoptosis. Inactivation of tumor cell apoptosis thus contributes to the development of cancer spreading and resistance to therapy [1]. The development of multiple drug resistance (MDR) characterized by intrinsic P-glycoprotein (P-gp) expression, is a general phenomenon occurring in several tumors, including hepatocellular carcinoma (HCC) [2]. A large number of chemical, physical or environmental stimuli may lead to P-gp expression, which can enhance cell survival in adverse conditions [3]. The expression of P-gp must be considered a type of marker of tumor aggressivity and is often associated with expression of the angiogenetic phenotype in HCC cell lines, as we have recently shown [4,5]. Since P-gp expression seems to be controlled by COX-2 activity, COX-2 inhibitors could have an inhibitory effect on the MDR phenotype. We have recently shown that celecoxib, a specific inhibitor of COX2 activity, reverses MDR-positive HCC cells to apoptosis by a P-gp-dependent mechanism [6].

Apoptosis is not the only cell response to drugs, toxins and stress conditions. It has been suggested that another response to therapeutic interventions can involve autophagy and autophagic cell death. Autophagy is activated in response to $\gamma$-irradiation and various anticancer drugs $[7,8]$ and can also be considered as a tumor suppressor mechanism since defects in autophagy profoundly perturb organism development. The haploinsufficient essential mammalian autophagy gene, Beclin1, promotes carcinogenesis in mice, especially as liver cancer [9]. It has been demonstrated that Yoshida AH-130 hepatoma and primary HCC cells have lower autophagic activity than normal hepatocytes [10]. Acquired drug resistance to chemotherapy may cause resistance to cell cycle arrest and autophagy [11]. Apoptosis, autophagy and cell cycle progression require several regulator proteins, suggesting that they share the same molecular pathways [12]. COX-2 inhibitors may exert their anticancer activity by slowing down cell proliferation and inducing autophagy and cell-cycle arrest $[13,14]$. Cell-cycle progression is promoted by a number of cyclin-dependent kinases which have to complex with regulatory proteins, namely cyclins, to drive the cell through the cycle. They 
are negatively regulated by cell-cycle inhibitory proteins called cyclin-dependent kinase inhibitors, CKI. Two classes of CKI have been identified: the INK4 family, including $\mathrm{p} 16^{\mathrm{INK} 4 \mathrm{~b}}, \mathrm{p} 15^{\mathrm{INK} 4 \mathrm{a}}, \mathrm{p} 18$ INK4c and p19 ${ }^{\mathrm{INK} 4 \mathrm{~d}}$, which inhibit cyclin D associated kinases (cdk2, 4 and 6) and the Cip/Kip family, including $\mathrm{p} 21^{\mathrm{Cip} 1}, \mathrm{p} 27^{\mathrm{Kip} 1}$ and $\mathrm{p} 57$, that negatively regulate cyclin E/cdk2 and cyclin A/cdk2 complexes [15]. Interestingly, $\mathrm{p} 16^{\mathrm{INK} 4 \mathrm{~b}}, \mathrm{p} 21^{\mathrm{Cip} 1}$ and $\mathrm{p} 27^{\mathrm{Kip} 1}$, whose main function is to induce cell cycle arrest and apoptosis, induce autophagy [16]. p2 $7^{\text {Kip1 }}$ also can down-regulate P-gp [17]. Thus, enhancement of CKI signaling is particularly noteworthy among the putative molecular targets other than COX-2 in CLX-mediated in vitro antiproliferative effects in cancer cells $[13,14]$.

On these bases, this study was designed to address the following questions: 1) Is the CLXinduced inhibition of MDR-positive HCC cell growth due to cell-cycle arrest? 2) Is cell-cycle arrest related to induction of autophagy? 3) Does CKI activation regulate cell cycle, autophagy and apoptosis of MDR-positive HCC cells? 4) Does P-gp directly regulate the expression of cell-cycle progression and autophagy-related proteins such as HGF/MET, Bcl-2, Beclin1 and CKI? 


\section{MATERIALS AND METHODS}

2.1. Cell lines. Experiments were performed on a human HCC line PLC/PRF/5, by using the drug-sensitive clone (P5) and the highly MDR-positive subclone P1(0.5) [18]. The P1(0.5) subclone was developed by serial prolonged exposure to increasing concentrations of doxorubicin (Pfizer Global R \& D, USA) starting from parental P5 cells, and subsequently cultured in DMEM containing $0.5 \mu \mathrm{g} / \mathrm{mL}$ doxorubicin and $10 \%$ fetal bovine serum (FBS), as shown elsewhere [5]. The cell lines were cultured at $37^{\circ} \mathrm{C}$ in an atmosphere containing $5 \% \mathrm{CO}_{2}$.

2.2. Cell treatment. Doxorubicin-free, serum-free medium containing celecoxib (CLX) (2.5, $5,10$ and $20 \mu \mathrm{M})$ was used in all experiments.

2.3. Colony formation efficiency test. (P5) and the subclone P1(0.5) were seeded in triplicate onto 35-mm dishes containing agarose and DMEM and were treated with 2.5, 5, 10 and $20 \mu \mathrm{M}$ celecoxib in doxorubicin-free, serum-free medium. The plates were incubated at $37^{\circ} \mathrm{C}$, in $5 \% \mathrm{CO}_{2}$, for 2 weeks and photographed.

2.4. Cell cycle analysis by flow cytometry. 50000 cells were plated onto 60-mm Petri dishes and experiments were done in triplicate; cells were treated with $2.5,5,10$ and $20 \mu \mathrm{M} \mathrm{CLX}$ for $24 \mathrm{~h}$. Cells were fixed with $70 \%$ ethanol at $48^{\circ} \mathrm{C}$. RNaseA $(20 \mu \mathrm{g} / \mathrm{mL})$ and PI $(50 \mu \mathrm{g} / \mathrm{mL})$ were then added, and cell suspensions were incubated for $30 \mathrm{~min}$ in the dark. Stained cells were analyzed on a FACScan flow cytometer (FACSCalibur, BD Biosciences, Franklin Lakes, NJ).

2.5. Cell viability. $P 5$ and $P 1(0.5)$ cells were plated in $60-\mathrm{mm}$ Petri dishes and grown in DMEM supplemented with 10\% FBS. On the next day, cells were treated with 2.5, 5, 10 and $20 \mu \mathrm{M}$ celecoxib in doxorubicin-free, serum-free medium. After $48 \mathrm{~h}$, the dead cells were identified using the trypan blue staining test. Adherent cells were detached, resuspended in DMEM, and both adherent and suspended cells were mixed with an equal volume of $0.04 \%(\mathrm{w} / \mathrm{v})$ trypan blue. The percentage of dead cells stained was determined by counting. For MTT assay, 25,000 cells were plated in each well of a 96-well plate. After $48 \mathrm{~h}$, the cells were treated with celecoxib 2.5, 5, 10 
and $20 \mu \mathrm{M}$. An equal volume of DMSO was added to the control well; after $48 \mathrm{~h}, 10 \mu \mathrm{L}$ MTT (5 $\mathrm{mg} / \mathrm{mL}$ ) in growth medium were added per well, and the plates were incubated at $37^{\circ} \mathrm{C}$ for $4 \mathrm{~h}$. The reduced MTT dye in each well was solubilized in $200 \mu \mathrm{L}$ DMSO. Absorbance was measured on an ELX-800 microplate reader at $540 \mathrm{~nm}$.

2.6. Immunocytochemistry. Cells were plated onto a coverslip and grown in culture medium containing $10 \%$ FBS. After $24 \mathrm{~h}$, cells were treated with 2.5, 5, 10 and $20 \mu \mathrm{M}$ celecoxib in doxorubicin-free, serum-free medium. For immunocytochemistry, cells, after $24 \mathrm{~h}$, were fixed with paraformaldehyde $(3.7 \% \mathrm{w} / \mathrm{v})$, permeabilized with $0.05 \%(\mathrm{v} / \mathrm{v})$ Triton X-100 for $10 \mathrm{~min}$, blocked with $10 \%(\mathrm{w} / \mathrm{v})$ normal goat serum, then incubated overnight with primary antibodies at an appropriate dilution $\underline{(1: 100)}$ p16 ${ }^{\text {ink4 }}$ (mouse monoclonal), p $21^{\text {cip } 1}$ (rabbit polyclonal) p $27^{\text {kip } 1}$ (rabbit polyclonal), p53 (mouse monoclonal), cyclin D1 (mouse monoclonal), cyclin E (rabbit polyclonal), TGF $\beta 1$ (mouse monoclonal) and E2F (rabbit polyclonal) (Santa Cruz Biotechnology, USA). After washing, samples were incubated with Dako-Envision dual link secondary antibody at room temperature. Then the slides were colored with chromogen DAB, countercolored with hematoxylin and mounted with Eukitt. Total expression and site of expression of proteins were determined by counting 100 cells in 10 different microscope fields. For immunofluorescence studies, cells were fixed with paraformaldehyde $(3.7 \% \mathrm{w} / \mathrm{v})$ after $1 \mathrm{~h}$, permeabilized with $0.05 \%(\mathrm{v} / \mathrm{v})$ Triton X-100 for 10 min, blocked with $10 \%$ (w/v) normal goat serum, and samples were incubated overnight with primary antibodies for Beclin1 (rabbit polyclonal), Bcl-2 (rabbit polyclonal) and LC3 (rabbit polyclonal) (Santa Cruz Biotechnology, USA) and then incubated with FITC- or TRITC-conjugated

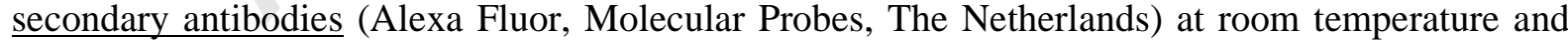
analyzed with Nikon fluorescent microscope.

2.7. Western blot analysis. Cells were lysed in a buffer $(50 \mathrm{mM}$ Tris/ $\mathrm{HCl} \mathrm{pH} 7.4,150 \mathrm{mM}$ $\mathrm{NaCl}, 5 \mathrm{mM} \mathrm{MgCl} 2,1 \% \mathrm{TX}-100,1 \mathrm{mM}$ EGTA, 1mM DTT), containing protease inhibitors and NaF 0.1 M. Protein concentrations were determined with the Bradford assay. The lysates were centrifuged and proteins $(25 \mu \mathrm{g})$ were subjected to electrophoresis on Tris-glycine SDS 
polyacrylamide gel. After blotting onto nitrocellulose with filter papers, non-specific binding sites were blocked by incubation and carried out for $1 \mathrm{~h}$ at room temperature in phosphate buffered saline (PBS) with 5\% milk. The blots were then probed with primary antibodies at the appropriate dilution $\underline{\text { (1:500) }}$ overnight, $\mathrm{p} 16^{\mathrm{ink} 4}$ (mouse monoclonal), $\mathrm{p} 21^{\mathrm{cip} 1}$ (rabbit polyclonal), $\mathrm{p} 27^{\mathrm{kip} 1}$ (rabbit $\underline{\text { polyclonal), }}$ cyclin $\mathrm{D} \underline{\text { (mouse monoclonal) }}$ and $\mathrm{E} \underline{\text { (rabbit polyclonal)}}, \mathrm{pRb} \underline{\text { (goat polyclonal) }}$ and E2F (rabbit polyclonal) (Santa Cruz Biotechnology, USA), Bcl-2 (rabbit polyclonal), mTOR

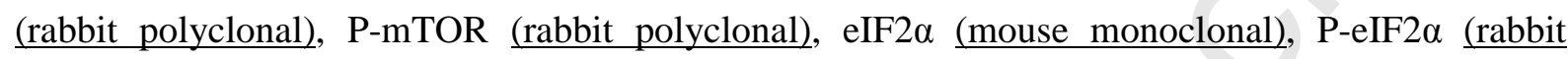
monoclonal), HGF (rabbit polyclonal), MET (mouse monoclonal) (Cell Signaling, USA). After being washed, blots were incubated with secondary antibodies 1:5000 (Bio-Rad Laboratories Ltd., Hemel Hemstead, UK) for $1 \mathrm{~h}$ at room temperature. Proteins were detected by enhanced chemiluminescence according to the manufacturer's instructions (Pierce Biotechnology, USA).

2.8. Incorporation of monodansylcadaverine (MDC). Cells were incubated with $0.05 \mathrm{mM}$ MDC in PBS at $37^{\circ} \mathrm{C}$ for 20 minutes. After incubation, cells were washed twice with PBS and immediately analyzed by Nikon fluorescence microscope.

2.9. Small interfering RNA transfection. Positive control GAPDH small interfering RNA (siRNA), sicontrol non-targeting siRNA and a pool of four different double-stranded RNA oligonucleotides directed against MDR1 (siGENOME SMARTpool, human ABCB1) were purchased from Dharmacon. P1(0.5) cells were seeded onto $60-\mathrm{mm}$ dishes to reach $30 \%$ to $50 \%$ confluence after $24 \mathrm{~h}$ of incubation, and transfected with a total of $100 \mathrm{nmol} / \mathrm{L}$ siRNA using LipofectAMINE 2000 (Invitrogen Life Technologies, Inc.) in antibiotic-free medium, according to the manufacturer's instructions. $72 \mathrm{~h}$ after transfection proteins were extracted for Western blot analysis and cells were analyzed for immunocytochemical analysis and flowcytometric analysis.

2.10.Statistical analysis. The significance of the differences between groups was determined by ANOVA. P <0.05 was considered significant. 


\section{RESULTS}

3.1. G1 phase arrest induced by CLX in MDR-positive HCC cell line. To clarify the mechanism underlying CLX-mediated in vitro antitumor action, the growth-inhibitory effect of various concentrations of $\operatorname{CLX}(2.5,5,10$ and $20 \mu \mathrm{M})$ was assessed in a serum-free, doxorubicinfree medium. Cell viability was measured by MTT assay and trypan blue exclusion test after cells were exposed to CLX for $48 \mathrm{~h}$. Clonogenic cell survival assays were also performed with low concentrations of CLX and colonies were counted after 14 days.

Cell viability was affected, in a concentration-dependent manner, especially in MDRpositive P1(0.5), but not in P5 cells either by MTT (Fig. 1A) or trypan blue exclusion test (Fig. 1B) and quantified by an increase in doubling time (38 \pm 0.9 vs $120 \pm 2.3)$. Flow cytometric analysis of $\underline{\mathrm{P} 5}$ and $\mathrm{P} 1(0.5)$ cell lines was performed after $48 \mathrm{~h}$ without CLX and serum, and it was found that both cell lines were in the same stage of the cell-cycle (Fig.1 C). CLX treatment induced concentration-dependent inhibition of cell growth in MDR-positive P1(0.5) cells, but not in P5 (Fig 1D and data not shown). Cell number and colony size were inversely related to the CLX concentration.

Whether CLX inhibition of MDR-positive cell growth was caused by cell-cycle arrest was also determined. Both P5 and P1(0.5) cells were treated with different concentrations of CLX in serum-free, doxorubicin-free medium and the phases of cell cycle distribution were determined by flow cytometric analysis (Fig. 2A and 2B). DNA content of P1(0.5) cells revealed that CLX caused an accumulation of G1 cells in an inversely concentration-dependent manner (Fig. 2B). Exposure to the lowest concentration of CLX $(2.5 \mu \mathrm{M})$ resulted in the most evident accumulation of cells in G1 phase. With increasing CLX concentrations, a gradual reduction in the accumulation of P1(0.5) cells in the G1 phase until the control value (from $70 \%$ to $53 \%$ ) was observed (Fig. 2B). This was associated with a concentration-independent decrease in the S fraction (from $20 \%$ to $11 \%$ ) and no significant effect on G2/M transition except for the decrease shown using CLX at $2.5 \mu \mathrm{M}$. This 
suggests that the inhibitory effect of CLX on P1(0.5) cell growth leads to G1 cell cycle arrest. At higher concentrations of CLX (10 and $20 \mu \mathrm{M})$, caused an increase of sub-G1 phase in P1(0.5) cells, consistent with an increase of apoptotic cells, as shown previously (Fig. 2B) [6]. On the contrary, no significant changes in DNA distribution of P5 cells were observed (Fig. 2C). Altogether, these data show that the inhibitory effect of CLX on MDR-positive cell growth leads to a cell-cycle inhibition primarily at the G1/S checkpoint as well as to apoptosis, depending on the drug concentration. Both events are likely to contribute to reduced cell growth of P1(0.5) cells triggered by CLX $10 \mu \mathrm{M}$.

\subsection{CLX-induced autophagy in MDR-positive HCC cell line during G1 phase arrest}

Since G1 arrest is frequently associated with activation of the autophagic process, we first verified whether CLX at low concentrations was able to stimulate the lysosomal vacuolar formation in $\mathrm{P} 1(0.5)$ cells by measuring the incorporation of monodansylcadaverine (MDC) into the lysosomes [19]. The vacuolar compartment was hardly detected as dispersed, faint basal MDC staining in P1(0.5) cells (Fig. 3A), while MDC-labeled vacuoles were present in $\mathrm{P} 1(0.5)$ cells following treatment with $2.5 \mu \mathrm{M}$ and $5 \mu \mathrm{M}$ CLX for 3 and 6 hours (Fig. 3A).

To have a better insight into the effect of CLX on the autophagic process, we looked for the mammalian microtubule-associated protein 1 light chain, LC3-II, a specific autophagosome/autolysosome marker, known as a structural component during autophagosome formation [20]. Since LC3-II is rapidly degraded with the sequestered material by lysosomal proteases, its turnover but not its concentration, is a good mirror of autophagic activity, as recently proposed by Tanida et al. [20]. We therefore measured the lysosomal turnover of LC3-II by immunocytochemical analysis (Fig 3B). LC3 granular staining can be quantified as 0.4 LC3-IIlabeled vacuoles/cell section in untreated $\mathrm{P} 1(0.5)$ cells, value comparable with that measured in HeLa cells. Treatment of P1(0.5) cells with CLX at a low concentration induced approximately a 4fold increase in the immunofluorescence of punctat of endogenous LC3 (Fig. 3B). Since the autophagic process can be dissected with agents acting at different phases, we measured the LC3-II 
turnover also in $\mathrm{P} 1(0.5)$ cells pre-incubated with $10 \mathrm{mM}$ 3-MA, an inhibitor of the sequestration phase $[21,22]$. As expected, accumulation of LC3-II-labeled vacuoles was prevented by the PI3kinase inhibitor (Fig. 3B).

Once it was shown that the lysosomal vacuolar system is activated by CLX, it was determined whether the activation of Beclin1, a novel Bcl-2 interacting protein needed for the nucleation of the autophagosome, was required for CLX-induced autophagy. P1(0.5) cells were stained immunocytochemically with anti-Beclin1 antibodies and immunoreactivity was measured. Immunoreactivity was hardly detected in cells not treated with CLX whereas it was clearly enhanced in CLX-treated cells, being already evident after $\underline{1 \mathrm{~h}}$ (Fig. 3C). Because Bcl-2, that is known to be an anti-apoptotic and anti-autophagic protein, was down-regulated in $10 \mu \mathrm{M}$ CLXtreated P1(0.5) [6], its expression was estimated after exposure to 2.5 and $5 \mu \mathrm{M}$ CLX. Bcl-2 expression decreased when P1(0.5) cells were exposed to CLX (Fig. 3D).

To verify whether CLX-mediated activation of the autophagic process was related to an unbalance equilibrium between the expression of $\operatorname{eIF} 2 \alpha$, the best known inducer of autophagy, and that of mTOR, the cell stress sensor and inhibitor of autophagy-induction [23], Western blot analysis was carried out. CLX up-regulated the phosphorylation of eIF2 $\alpha$, down-regulating mTOR phosphorylation in P1(0.5) cells, consistently with what was observed on autophagy (Fig. 3E).

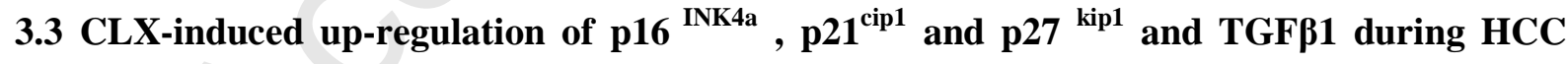 growth arrest}

To examine the molecular mechanism that may be underlying the changes in cell-cycle progression, autophagy and apoptosis, we investigated the levels of CKI expression, p16 ${ }^{\text {INK4a }}$, $\mathrm{p} 21^{\mathrm{Cip} 1}$ and $\mathrm{p} 27^{\mathrm{Kip} 1}$. CKIs are known to prevent the transition of cells from G1 to $\mathrm{S}$ phase. The treatment with $5 \mu \mathrm{M}$ and, especially $10 \mu \mathrm{M}$ CLX enhanced CKI expression in P1(0.5) but not in P5 cells, as measured by Western blot analysis (Fig. 4A). Because CKIs work in the nucleus and are also present in the cytoplasm as inactive proteins, an immunocytochemical study was performed 
(Fig. 4B). All three CKIs we measured increased at a nuclear level after CLX treatment. In particular, p2 $7^{\text {Kip } 1}$ expression increased about four times (Fig. 4C), largely confirming the Western blot results.

To date, TGF $\beta 1$ is considered to be the main growth inhibitory factor for epithelial cells acting in the late G1 phase upstream of CKI function [24]. Some HCC cells are known to exhibit an autocrine loop for TGF $\beta 1$ to regulate their growth. To assess whether this was the case, it was determined whether P1(0.5) cells produced TGF $\beta 1$ in response to CLX treatment to induce CKI expression. Quantification of the TGF $\beta 1$-expressing cells, as reported in Fig. 4D, showed a clear increase of TGF $\beta 1$ production in the CLX-treated P1(0.5) cells, but not in P5, consistently with the inhibitory effect on cell growth. We also examined p53 expression, since p53 is known to control p21 levels. No significant changes following CLX treatment (Fig. 4D) were found, indicating a p53-independent enhancement of p21 in P1(0.5) cells.

\subsection{Down-regulation of cyclin D1 and cyclin E, p-Rb, E2F, MET and ERK induced by CLX during HCC growth arrest}

Since the main function of CKI is the inhibition of the cyclin-dependent kinases, the downstream events linking CKI function to G1 arrest were investigated. The effects of $10 \mu \mathrm{M} \mathrm{CLX}$ on cyclin D1 and E expression level, known to be involved in G1 and G1/S cell cycle progression, were examined. Fig. 5 shows that CLX treatment of P1(0.5), but not of P5, induced a slight decrease in cyclin D1 expression and about a three-fold reduction in cyclin E protein levels as determined by Western blot (Fig. 5A). This result was confirmed by immunocytochemical analysis (Fig. 5B).

The product of the $\mathrm{Rb}$ gene prevents cells from entering into $\mathrm{S}$ phase. G1/S progression is mediated by cyclin D1 and cyclin E in complex with the cyclin-dependent kinases, which phosphorylate $\mathrm{Rb}$, leading to inactivation of its growth-suppressive function and resulting in cellcycle transition. We, therefore, investigated whether CLX treatment could affect phosphorylated $\mathrm{Rb}$ 
(pRb). We found that $\mathrm{pRb}$ expression was decreased in P1(0.5), but again not in P5, following CLX treatment, consistently with a down-regulating expression of cyclin E (Fig. 5A).

Because $\mathrm{pRb}$ inhibits cell-cycle progression by interacting with transcription factors such as $\mathrm{E} 2 \mathrm{~F}$, when $\mathrm{Rb}$ becomes phosphorylated, E2F is released and stimulates cell proliferation. Thus, further experiments were carried out to check whether CLX treatment might influence E2F expression. A reduction in E2F expression in P1(0.5) cells was evident by Western blotting (Fig. 5A) and quantification of the immunocytochemical analysis demonstrated a 5-fold decrease in E2F expression levels in P1(0.5) cells, while no significant changes were observed in P5, following CLX treatment (Fig. 5B).

Since some evidence indicates a critical role of the HGF/MET and downstream MEK/ERK pathway in the control of hepatocyte proliferation both in vitro and in vivo as well as of $\mathrm{p} 21^{\text {Cip1 }}$ expression [25], additional experiments were carried out to detect and quantify MET and ERK expression after CLX treatment. Western blot analysis of these experiments showed that CLX down-regulated MET and ERK expression only in P1(0.5) cells (Fig. 5A).

\subsection{CLX-induced $\mathrm{p}^{\mathrm{kip} 1}$ and Beclin1 up-regulation, sub G1 peak and G1 cell accumulation in P1 cells are mediated by $P$-gp expression}

To validate $\mathrm{P}$-gp as primary target responsible for the in vitro anti-proliferative, proautophagic and pro-apoptotic effect of CLX, further experiments were performed. The expression of P-gp was specifically down-regulated by transient transfection with an MDRlsiRNA. As controls, parallel cultures were either not transfected or transfected with an inefficient duplex oligonucleotide not targeting MDR1mRNA (sham-transfected). Proper conditions were assessed to achieve optimal down-regulation of P-gp expression, which was monitored by immunoblotting determination of P-gp protein level (Fig. 6A). MDRlsiRNA transfection successfully downregulated P-gp expression in MDRlsiRNA transfected P1(0.5) culture (Fig. 6A). In MDRlsiRNAtransfected cells, P-gp protein level, normalized against the actin protein level, was reduced by 
$>90 \%$, as measured by densitometry (data not shown). A parallel set of cultures was performed to evaluate $\mathrm{p} 27^{\mathrm{Kip} 1}$ expression by Western blot and immunocytochemistry as well as Beclin 1 expression and DNA distribution by fluocytometric analysis. The MDRl siRNA induced an increase in the levels of $\mathrm{p} 27^{\mathrm{Kip} 1}$ expression under the basal conditions, as measured by Western blot (Fig. 6A). However, immunocytochemical analysis indicated that, when P1(0.5) cells were exposed to CLX, nuclear $\mathrm{p} 27^{\mathrm{Kip} 1}$ expression increased in a concentration-dependent manner in untransfected and sham-transfected cultures (Fig. 6B). Immunocytochemistry analysis of Beclin1 showed that its levels in CLX treated-MDRlsiRNA-transfected P1(0.5) cells were maintained at approximately the value in MDRI siRNA transfected P1(0.5) culture, while no effect on MDRI siRNA was observed under basal conditions of untreated cells (Fig. 6C). Consequently, flowcytometric analysis of DNA distribution showed no changes in either sham-transfected or MDRlsiRNA transfected P1(0.5) cells in comparison with un-transfected cells. On the contrary, it demonstrated the disappearance of the $10 \mu \mathrm{M}$ CLX-induced sub-G1 peak and G1 cell accumulation in MDRlsiRNA-transfected P1(0.5) cells compared with CLX-treated untransfected cells (Fig. 6D). Because the MDRlsiRNA-mediated CLX effects on P1(0.5) growth might depend on the action of MDR1 on the HGF/MET autocrine loop, we also investigated whether P-gp siRNA could modulate HGF/MET expression as well as that of potential downstream mediators. It was found that MDRI siRNA down-regulated the levels of expression of both HGF and MET as well as that of Bcl-2, a candidate mediator of CLX effects, without significantly affecting p27 $7^{\mathrm{Kip} 1}$ or Beclin1 expression (Fig. 6A and C). 


\section{DISCUSSION}

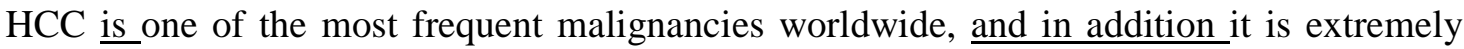
resistant to currently used chemotherapeutics [26]. We present here evidence demonstrating that P$\mathrm{gp}$, the protein encoded by the MDR1 gene, regulates the autocrine loop mediated by HGF/MET in P1(0.5) cells, leading to resistance to drug-mediated growth inhibition. CLX, the specific inhibitor of COX-2 activity, effectively overcomes P-gp mediated drug resistance and suppresses the anchorage-independent growth of resistant HCC cells by inducing G1 arrest, autophagy and apoptosis. In addition, CLX decreases Bcl-2 expression by down-regulation of the MET pathway and phosphorylation of mTOR in human HCC MDR-positive cancer cells.

High levels of Bcl-2 sustain the drug-resistant phenotype, while down-regulation of Bcl-2 is associated with reduced drug resistance [27,28]. In the present study the role of Bcl-2 in the negative regulation of Beclin1 and Bax expression and resistance to autophagy and apoptosis was found to correlate with phosphorylation of mTor and ERK MAPK.

Some evidence supports the key role of Bcl-2 in the CLX effect of suppressing cell drug resistance. The crosstalk between autophagy and apoptosis is partly mediated by the functional and physical interaction between Beclin1, an essential autophagy gene, or Bax, the best known proapoptotic factor, and Bcl-2, one of the paragmatic apoptosis-inhibitory proteins $[29,30]$. When Bcl2 interacts with calcineurin, it allows ERK phosphorylation by Raf 1 and cell-cycle progression [31]. Thus, Bcl-2 function seems to depend on its localization, since only endoplasmic reticulumtargeted Bcl-2 inhibits autophagy and only mitochondria-targeted Bcl-2 inhibits apoptosis [29]. Cytosolic Bcl-2 might actively maintain cell survival by favoring cell-cycle progression.

Several mechanisms have been proposed to explain the antiproliferative effects of COX-2 inhibitors, besides their action as COX-2 activity inhibitors [13,14]. In this study, it is shown that CLX at low concentration induced autophagy whereas at higher concentration apoptosis as confirmed by the appearance of the subG1 peak according to flow cytometric analysis only in HCC 
cells over-expressing P-gp (Fig. 2B and 2C). The lower concentrations of CLX (2.5 and $5 \mu \mathrm{M})$ were unable to trigger apoptosis in $\mathrm{P} 1(0.5)$ cells, while they were effective in activating autophagy, suggesting that autophagy could be the earliest event involved in the reversal of drug-resistance by CLX, operating upstream of apoptosis. The induction of autophagy in P1(0.5) cells by CLX $\underline{\text { at low }}$ concentration is supported by the down-regulation of mTOR associated with up-regulation of eIF2 $\alpha$, leading to enhancement of Beclin1 expression within 30 minutes, which causes the accumulation of LC3-II-labeled autophagosomes and then MDC-labeled autolysosomes. The observation made in the present work that CLX at concentration lower than $10 \mu \mathrm{M}$ triggers autophagy whereas at higher concentration causes apoptosis in P-gp over-expressing HCC cell lines might be important to explain controversial results reported in the literature concerning the antiproliferative effect of CLX. In fact, CLX effect on cancer cells, at least HCC cell lines, would depend on the expression of P-gp and CLX concentration in the microenvironment. To obtain the "killing" effect by CLX (apoptotic death) at least two conditions should be present, P-gp overexpression and concentration of the drug of about $10 \mu \mathrm{M}$ or more. Without both conditions, $\underline{\text { CLX may leads to autophagy or to COX-2 activity inhibition only, slowing down the growth rate of }}$ cancer without killing cancer cells. With regards this point, autophagy can be considered a mechanism by which cells, also cancer cells, survive to stress, expecially those characterized by hypoxia and/or DNA denaturation.

$\underline{\text { Celecoxib-induced accumulation of } \mathrm{P} 1(0.5) \text { in } \mathrm{G}_{0} / \mathrm{G}_{1}}$ phase together autophagy induction might be $\underline{\text { seen as a sort of defence by MDR positive cells to survive to CLX induced toxicity. It is possible }}$ that in case autophagy should not evolve to autophagic death or autophagic-induced apoptosis, MDR positive cells could recover and quickly start again to proliferate. If it is the case, treatment with CLX should allowed to reach drug concentration to cause apoptosis, otherwise it could favor cancer growth. It is important to consider that targeting autophagy to control cancer growth it is probably unsafe at present, as the knowledge of the entire mechanism regulating autophagyapoptosis is too much partial to be exploited for therapy attempts. As suggested recently, we agree 
$\underline{\text { that precaution should be used before using drugs that target autophagy as the results could be quite }}$ different from what wait for [32]

Although autophagy has received attention recently, there is still debate about its role as a mechanism for cell survival or cell death under certain conditions. As a survival mechanism, autophagy is known to prevent apoptosis especially to handle cell damages caused by stress condition. However, during prolonged starvation or oxidative stress, autophagy can switch to apoptosis or autophagic cell death [33]. For these reasons autophagy might inhibit cancer growth by regulating cell mass. Recent studies have shown that autophagy has multiple roles in the regulation of cell death, differentiation and antimicrobial response in mammals [34,35]. Conditions known to induce autophagy inhibit cell growth by inducing cell-cycle arrest, indicating that cell-cycle progression largely depends on cell protein mass [22]. Consistently, here the flow cytometric analysis revealed that CLX at low concentration caused accumulation of cells in G1 phase that decreased from 2.5 to $10 \mu \mathrm{M}$ when the sub-G1 peak appeared, indicating a shift to apoptosis [6].

Although p53 is a well known mediator of cell-cycle arrest, apoptosis and autophagy, in the present work the CLX effect on MDR-positive cells appeared to be p53-independent, even if it was mediated by enhanced $\mathrm{p} 21^{\text {Cip1 }}$ expression. We hypothesize the involvement of the pathway of ERK1/2, because CLX reduces the phosphorylation of ERK1/2 in P1(0.5) cells. This event results in enhanced expression of $\mathrm{p} 16^{\mathrm{INK} 4 \mathrm{~b}}, \mathrm{p} 21^{\mathrm{Cip} 1}$ and, particularly, $\mathrm{p} 27^{\mathrm{Kip} 1}$, whose main function is to negatively regulate cell cycle progression $[13,14]$. The observation that CLX enhances CKIs, especially $\mathrm{p} 27^{\mathrm{Kip} 1}$, which inhibit cell growth by acting on G1 phase of the cell cycle (Fig.4) supports the concept that drugs acting on cell cycle could be used for cancer treatment. The hypothesis is in line with the observation that elemene, a natural antitumor drug, sensitizes chemoresistant ovarian carcinoma cells to cysplatin-induced growth suppression through up-regulation of $\mathrm{p} 53$, p2 ${ }^{\text {Cip } 1}$, $\mathrm{p} 27^{\text {Kip1 }}$, Gadd 45 and down-regulation of cdk2-cyclin B1, resulting in G2/M arrest ( $\underline{36}$ ) and overexpression of p27 $7^{\mathrm{Kip} 1}$ induced autophagy. The hypothesis is supported by other reports [37-39]. 
The concept of cell-cycle mediated drug resistance and how novel CKIs are used to overcome this resistance led us to study the effects of CLX on the expression of both cyclins D1 and E. We found that CLX down-regulates cyclins D1 and E in P1(0.5), suggesting that the coxib may prove to be a valuable tool for the inhibition of cyclin D1/cdk2 and cyclin E/cdk4 complex in resistant HCCs. As a consequence, CLX also down-regulates the phosphorylation of RB, whose main function is to promote the G1/S transition. In line with data shown in the present work, Narayanan et al. (2003) report G1 arrest of prostate cancer cells by CLX by modulating cell cycle regulatory proteins such as cyclin D1 and cyclin E, pRB, p2 $7^{\mathrm{Kip} 1}$ and $\mathrm{p} 21^{\mathrm{Cip} 1}(13)$. On the whole, these data support the concept of sharing key molecules such as Bcl-2, CKI, TGF $\beta$ among the pathways of autophagy, cell cycle progression and apoptosis $[\underline{23,30]}$.

It has been proposed that drug resistance can be overcome by conventional therapies by activating the autophagic process $[7,8, \underline{40,41]}$. Rapamycin, a mTOR inhibitor and a well known autophagy inducer, selectively reverses drug resistance in Akt overexpressing and PTEN deficient lymphomas [42] or it cooperates with the selective MET inhibitor PHA56672 to suppress growth and invasion of lung cancer [43].

Exposure to radiation induces autophagy, G1 arrest and $\mathrm{p} 27^{\text {Kip1 }}$ expression in radiosensitive cell lines, while the growth of resistant cells is associated with low levels of p27 ${ }^{\text {Kip } 1}$ expression [44].

It has been reported that autophagy can degrade NFkB-inducing kinase and IkB kinase, leading to NFkB inactivation, one of the mechanisms proposed for reversal of drug/immunomediated resistance [45]. In line with these observations, here the sensitizing effects of CLX in human MDR-positive HCC cells appear to help to switch off P-gp expression. First, the antiproliferative and pro-apoptotic effect of CLX, observed as G1 cell accumulation and appearance of sub-G1 peak in DNA distribution, appeared to be dependent on P-gp expression, because suppression of P-gp by MDRlsiRNA makes CLX ineffective. Interestingly, silencing P-gp expression also prevents activation of autophagy and $\mathrm{p} 27^{\mathrm{Kip} 1}$ by CLX and these findings fits with our previous data on prevention of apoptosis [6]. 
Data shown in the present study are schematically diagrammed in Fig. 7. Overexpression of Bcl-2 can be detrimental for response of tumor cells to drug-mediated autophagy/cell cycle arrest/apoptosis and Bcl-2 might be proposed as a main target for reversal of drug resistance.

In conclusion, to the best of our knowledge, this is the first report showing that CLX induces growth suppression by stimulating autophagy, besides apoptosis and G1 arrest, and identifies Bcl-2 as a possible common mediator of these events. These results illustrate that P-gp is responsible for the in vitro antiproliferative, pro-autophagic and pro-apoptotic effect of CLX. MDR1 siRNA downregulates the levels of expression of both HGF and MET and CLX decreases Bcl-2 expression by down-regulation of the MET pathway in P1(0.5) cells. For these reasons the CLX effects on P1(0.5) might depend on the action of P-gp on the HGF/MET autocrine loop. In the future, it would be useful to extend these preclinical in vitro results to evaluate the effect of the above used concentrations of CLX in mouse tumor models to support potential clinical studies.

\section{REFERENCES}

[1] Thompson CB. Apoptosis in the pathogenesis and treatment of disease. Science 1995;267:145662.

[2] Ling V. Multidrug resistance: molecular mechanisms and clinical relevance. Cancer Chemother Pharmacol 1997;40: Suppl:S3-8.

[3] Cheng SC, Zhou J, Xie Y. P-glycoprotein expression induced by glucose depletion enhanced the chemosensitivity in human hepatocellular carcinoma cell-lines. Cell biology international 2005;4:269-75.

[4] Lasagna N, Fantappie O, Solazzo M, Morbidelli L, Marchetti S, Cipriani G et al. Hepatocyte growth factor and inducible nitric oxide synthase are involved in multidrug resistance-induced angiogenesis in hepatocellular carcinoma cell lines. Cancer Res 2006;66:2673-82. 
[5] Fantappie O, Masini E, Sardi I, Raimondi L, Bani D, Solazzo M et al. The MDR phenotype is associated with the expression of COX-2 and iNOS in a human hepatocellular carcinoma cell line. Hepatology 2002;35:843-52.

[6] Fantappie O, Solazzo M, Lasagna N, Platini F, Tessitore L, Mazzanti R. P-glycoprotein mediates celecoxib-induced apoptosis in multiple drug-resistant cell lines. Cancer Res 2007;67:4915-23.

[7] Rubinsztein DC, Gestwicki JE, Murphy LO, Klionsky DJ. Potential therapeutic applications of autophagy. Nature reviews 2007;6:304-12.

[8] Kondo Y, Kanzawa T, Sawaya R, Kondo S. The role of autophagy in cancer development and response to therapy. Nat Rev Cancer 2005;5:726-34.

[9] Qu X, Yu J, Bhagat G, Furuya N, Hibshoosh H, Troxel A et al. Promotion of tumorigenesis by heterozygous disruption of the beclin 1 autophagy gene. J Clin Invest 2003;112:1809-20.

[10] Canuto RA, Tessitore L, Muzio G, Autelli R, Baccino FM. Tissue protein turnover during liver carcinogenesis. Carcinogenesis 1993;14:2581-7.

[11] Liang J, Shao SH, Xu ZX, Hennessy B, Ding Z, Larrea M et al. The energy sensing LKB1AMPK pathway regulates p27(kip1) phosphorylation mediating the decision to enter autophagy or apoptosis. Nature cell biology 2007;9:218-24.

[12] Levine B. Cell biology: autophagy and cancer. Nature 2007;446:745-7.

[13] Narayanan BA, Condon MS, Bosland MC, Narayanan NK, Reddy BS. Suppression of Nmethyl-N-nitrosourea/testosterone-induced rat prostate cancer growth by celecoxib: effects on cyclooxygenase-2, cell cycle regulation, and apoptosis mechanism(s). Clin Cancer Res 2003;9:3503-13.

[14] Zhang GS, Liu DS, Dai CW, Li RJ. Antitumor effects of celecoxib on K562 leukemia cells are mediated by cell-cycle arrest, caspase- 3 activation, and downregulation of Cox-2 expression and are synergistic with hydroxyurea or imatinib. American journal of hematology 2006;81(4):242-55. 
[15] Sherr CJ, Roberts JM. CDK inhibitors: positive and negative regulators of G1-phase progression. Genes \& development 1999;13:1501-12.

[16] Komata T, Kanzawa T, Takeuchi H, Germano IM, Schreiber M, Kondo Y et al. Antitumour effect of cyclin-dependent kinase inhibitors (p16(INK4A), p18(INK4C), p19(INK4D), p21(WAF1/CIP1) and p27(KIP1)) on malignant glioma cells. Br J Cancer 2003;88:1277-80.

[17] Xing H, Wang S, Hu K, Tao W, Li J, Gao Q et al. Effect of the cyclin-dependent kinases inhibitor p27 on resistance of ovarian cancer multicellular spheroids to anticancer chemotherapy. Journal of cancer research and clinical oncology 2005;131:511-9.

[18] MacNab GM, Alexander JJ, Lecatsas G, Bey EM, Urbanowicz JM. Hepatitis B surface antigen produced by a human hepatoma cell line. Br J Cancer 1976;34:509-15.

[19] Bampton ET, Goemans CG, Niranjan D, Mizushima N, Tolkovsky AM. The dynamics of autophagy visualized in live cells: from autophagosome formation to fusion with endo/lysosomes. Autophagy 2005;1:23-36.

[20] Tanida I, Minematsu-Ikeguchi N, Ueno T, Kominami E. Lysosomal turnover, but not a cellular level, of endogenous LC3 is a marker for autophagy. Autophagy 2005;1:84-91.

[21] Gordon PB, Seglen PO. Autophagic sequestration of [14C]sucrose, introduced into rat hepatocytes by reversible electro-permeabilization. Exp Cell Res 1982;142:1-14.

[22] Tessitore L, Bonelli G, Cecchini G, Autelli R, Amenta JS, Baccino FM. Regulation of protein turnover versus growth state. Studies on the mechanism(s) of initiation of acidic vacuolar proteolysis in cells of stationary ascites hepatoma. Biochem J 1988;251:483-90.

[23] Levine B, Yuan J. Autophagy in cell death: an innocent convict? J Clin Invest 2005;115:267988.

[24] Massague J. G1 cell-cycle control and cancer. Nature 2004;432:298-306.

[25] Ilyin GP, Glaise D, Gilot D, Baffet G, Guguen-Guillouzo C. Regulation and role of p21 and p27 cyclin-dependent kinase inhibitors during hepatocyte differentiation and growth. Am J Physiol Gastrointest Liver Physiol 2003;285:G115-127. 
[26] Grude P, Conti F, Mennecier D, Louvel A, Houssin D, Weill B et al. MDR1 gene expression in hepatocellular carcinoma and the peritumoral liver of patients with and without cirrhosis. Cancer Let. $2002 ; 186: 107-13$.

[27] Fu D, Shi Z, Wang Y. Bcl-2 plays a key role instead of mdr1 in the resistance to hexadecylphosphocholine in human epidermoid tumor cell line KB. Cancer Lett 1999;142:147-53. [28] Guo XZ, Shao XD, Liu MP, Xu JH, Ren LN, Zhao JJ et al. Effect of bax, bcl-2 and bcl-xL on regulating apoptosis in tissues of normal liver and hepatocellular carcinoma. World J Gastroenterol 2002;8:1059-62.

[29] Pattingre S, Tassa A, Qu X, Garuti R, Liang XH, Mizushima N et al. Bcl-2 antiapoptotic proteins inhibit Beclin 1-dependent autophagy. Cell 2005;122:927-39.

[30] Maiuri MC, Le Toumelin G, Criollo A, Rain JC, Gautier F, Juin P et al. Functional and physical interaction between Bcl-X(L) and a BH3-like domain in Beclin-1. Embo J 2007;26:252739.

[31] Gary-Gouy H, Sainz-Perez A, Bismuth G, Ghadiri A, Perrino BA, Dalloul A. Cyclosporin-A inhibits ERK phosphorylation in B cells by modulating the binding of Raf protein to Bcl2. Biochem Biophys Res Commun 2006;344:134-9.

[32] Eisenberg-Lerner A, Kimchi A. The paradox of autophagy and its implication in cancer etiology and therapy. Apoptosis. 2009; Jan 27. [Epub ahead of print]

[33] Gozuacik D, Kimchi A. Autophagy as a cell death and tumor suppressor mechanism. Oncogene 2004;23:2891-906.

[34] Mizushima N, Levine B, Cuervo AM, Klionsky DJ. Autophagy fights disease through cellular self-digestion. Nature 2008;451:1069-75.

[35] Levine B, Deretic V. Unveiling the roles of autophagy in innate and adaptive immunity. Nat Rev Immunol 2007;7:767-77. 
[36] Li C, Potuschak T, Colon-Carmona A, Gutierrez RA, Doerner P. Arabidopsis TCP20 links regulation of growth and cell division control pathways. Proc Natl Acad Sci U S A 2005;102:12978-83.

[37] Brown KA, Roberts RL, Arteaga CL, Law BK. Transforming growth factor-beta induces Cdk2 relocalization to the cytoplasm coincident with dephosphorylation of retinoblastoma tumor suppressor protein. Breast Cancer Res 2004;6:R130-9.

[38] Ishii T, Matsuse T, Masuda M, Teramoto S. The effects of S-phase kinase-associated protein 2 (SKP2) on cell cycle status, viability, and chemoresistance in A549 lung adenocarcinoma cells. Experimental lung research 2004;30:687-703.

[39] Ping B, He X, Xia W, Lee DF, Wei Y, Yu D et al. Cytoplasmic expression of p21CIP1/WAF1 is correlated with IKKbeta overexpression in human breast cancers. Int J Oncol 2006;29:1103-10. [40] Kessel D, Reiners JJ, Jr., Hazeldine ST, Polin L, Horwitz JP. The role of autophagy in the death of L1210 leukemia cells initiated by the new antitumor agents, XK469 and SH80. Mol Cancer Ther 2007;6:370-9.

[41] Kuo PL, Hsu YL, Cho CY. Plumbagin induces G2-M arrest and autophagy by inhibiting the AKT/mammalian target of rapamycin pathway in breast cancer cells. Mol Cancer Ther 2006;5:3209-21.

[42] Wendel HG, Malina A, Zhao Z, Zender L, Kogan SC, Cordon-Cardo C et al. Determinants of sensitivity and resistance to rapamycin-chemotherapy drug combinations in vivo. Cancer Res 2006;66:7639-46.

[43] Ma PC, Schaefer E, Christensen JG, Salgia R. A selective small molecule c-MET Inhibitor, PHA665752, cooperates with rapamycin. Clin Cancer Res 2005;11:2312-9.

[44] Yao M, Kargman S, Lam EC, Kelly CR, Zheng Y, Luk P et al. Inhibition of cyclooxygenase-2 by rofecoxib attenuates the growth and metastatic potential of colorectal carcinoma in mice. Cancer Res 2003;63:586-92. 
[45] Huerta-Yepez S, Vega M, Garban H, Bonavida B. Involvement of the TNF-alpha autocrineparacrine loop, via NF-kappaB and YY1, in the regulation of tumor cell resistance to Fas-induced apoptosis. Clinical immunology 2006;120:297-309.

\section{Acknowledgments}

This work is dedicated to "ad memoriam" of Prof. Luciana Tessitore. Luciana tragically died last summer in her beloved mountains while was climbing Monte Rosa together her son. She was an expert climber and an outstanding scientist, she dedicated her life to science, teaching and son. Ciao Luciana, we will not forget you.

Work supported by: University of East Piedmont “A. Avogadro" (LT). University of Florence and Associazione Toscana Ricerche and Cure Oncologiche (RM).

\section{Figure legends}

Figure 1. CLX inhibits the growth of MDR-positive cells. (A) MTT assay and (B) Trypan blue exclusion test; cells were exposed to $\operatorname{CLX}(2.5,5,10$ and $20 \mu \mathrm{M}$ for $48 \mathrm{~h})$; data shown are means \pm standard deviation (SD) of three independent experiments. (C) Cell cycle phase distribution of HCC

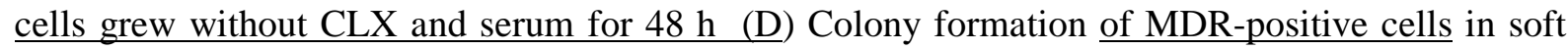
agar (day 14 after CLX treatment). Colonies showing more than 25 cells/colony were counted and presented as percentage of control. 
Figure 2. CLX induces accumulation of subG1 and G1 MDR-positive cells. (A) Representative DNA distribution of HCC cells treated with CLX at the indicated concentrations (0-2.5-5-10-20 $\mu \mathrm{M})$ for $24 \mathrm{~h}$. (B) Cell cycle phase distribution of $\mathrm{P} 1(0.5)$ cells treated with various concentrations of CLX for $24 \mathrm{~h}$. Each tabulated percentage represents the average of three independent experiments. (C) Cell cycle phase distribution of P5 cells treated with various concentrations of $\underline{\mathrm{CLX} \text { for } 24 \mathrm{~h}}$. Data shown are means $\pm \mathrm{SD}$.

Figure 3. CLX induces autophagy of P1(0.5) MDR positive cells. Cells were exposed to CLX for the indicated times and analyzed by Nikon fluorescence microscopy. (A) MDC (0.05 mM) incorporation in autolysosomes. (B) Staining of LC3-II punctat. Cells were exposed to CLX in the presence and absence of $10 \mathrm{mM}$ of $3 \mathrm{MA}$ for $1 \mathrm{~h}$. (C) Immunocytochemical analysis of Beclin1 expression after $1 \mathrm{~h}$ exposure of CLX. (D) Immunocytochemical analysis of Bcl-2 expression after $1 \mathrm{~h}$ exposure of CLX. Data are representative of three separate experiments and were calculated from inspection of at least 10 randomly chosen fields (40-50 cells/field). (E) Western Blot analysis of eIF2 $\alpha, \mathrm{P}$ - eIF2 $\alpha$, mTor and P-mTor in P5 and P1(0.5) cells at basal conditions and after treatment with CLX $5 \mu \mathrm{M}$ for 2 hours. Three separate experiments ere done and one representative of all is shown.

Figure 4. Up-regulation of CKI during CLX-induced P1 growth arrest and up-regulation of TGF- $\beta$ by $10 \mu \mathrm{M} \mathrm{CLX}$ for $3 \mathrm{~h}$ in P1(0.5) cells. Cells were cultured for $24 \mathrm{~h}$ in the presence of CLX. (A) Western blot analysis of $\mathrm{p} 16^{\mathrm{ink} 4 \mathrm{a}}, \mathrm{p} 21^{\mathrm{cip} 1}$ and $\mathrm{p} 27^{\mathrm{kip} 1}$ expression in HCC cell lines. (B) Expression of CKI by immunocytochemistry (10 $\mu \mathrm{M}$ CLX). (C) Quantification of the levels of nuclear CKI expression detected by immunocytochemistry; error bars represent SD of four independent experiments, ${ }^{*} \mathrm{p}<0.05$ versus control; \# $\mathrm{p}<0.05$ versus P5. (D) Quantification of TGF $\beta 1$ and $\mathrm{p} 53$ expression by immunocytochemical analysis $(10 \mu \mathrm{M} \mathrm{CLX})$. 
Figure 5. Down-regulation of the expression of proteins involved in the mitogenic signal transduction by $10 \mu \mathrm{M}$ CLX for $3 \mathrm{~h}$ in P1(0.5) cells. (A) Western blot analysis of cyclins D and E, pRb, E2F, ERK and MET expression. (B) Quantification of cyclin D, cyclin E and E2F expression by immunocytochemical analysis; data are means and error bars denote SD of three separate experiments, $* \mathrm{p}=0.05$.

Figure 6. Suppression of P-gp expression by MDR1siRNA prevents CLX-induced enhancement of p2 $7^{\text {kip1 }}$ expression and Beclin1, G1 arrest and apoptosis in P1(0.5) cells. (A) Representative Western blot of P-gp, HGF, MET, Bcl-2 and p27 $7^{\text {kip1 }}$. (B) Levels of p27 $7^{\text {kip1 }}$ expression by immunocytochemical analysis after CLX treatment and MDR1siRNA and nuclear quantification of $\mathrm{p} 27^{\mathrm{kip} 1}$. (C) Immunofluorescence of Beclin1. (D) DNA distribution by fluocytometric analysis, * $^{2}$ $\mathrm{p}<0.005$.

Figure 7. Hypothetical model of how CLX induces autophagy, cell cycle arrest and apoptosis in $\mathrm{P} 1(0.5)$ cells. 

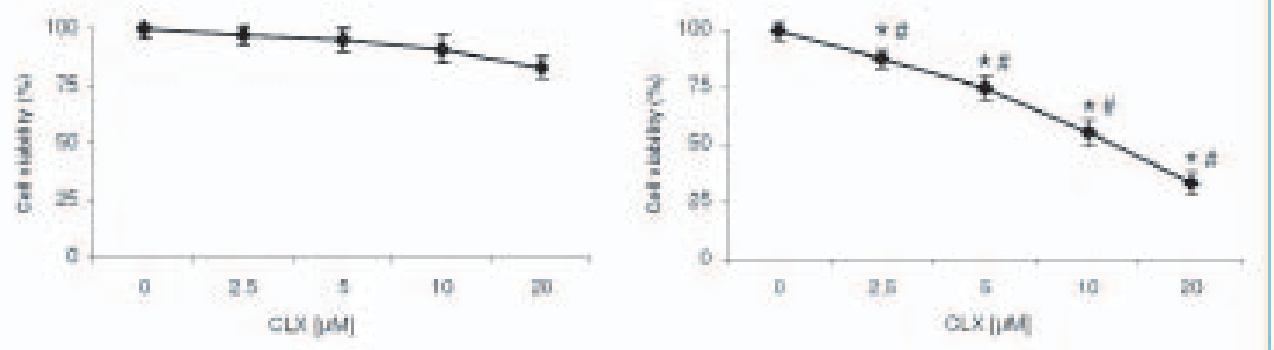

\section{Fig. 1B}
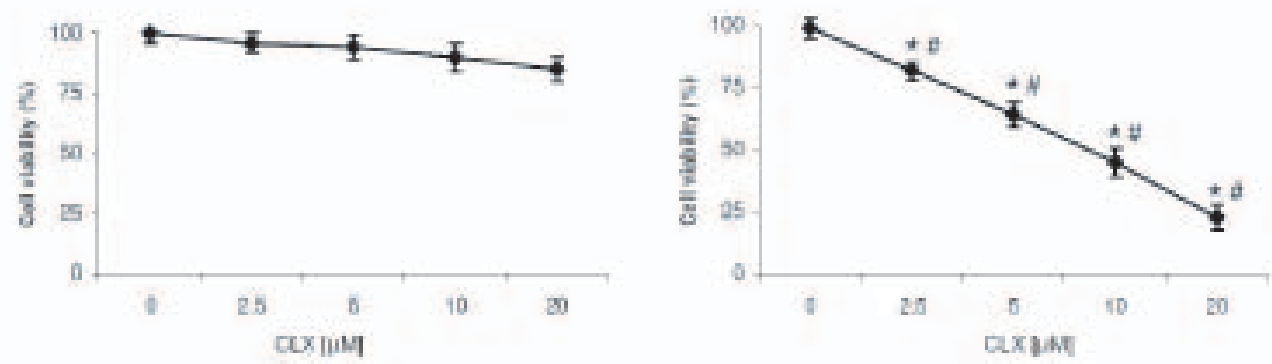

Fig. 1C

\begin{tabular}{c|cccc} 
Cell Lines & $\begin{array}{c}\text { Sub G1 } \\
(\%)\end{array}$ & $\begin{array}{c}\text { Go/G1 } \\
(\%)\end{array}$ & $\begin{array}{c}\text { S } \\
(\%)\end{array}$ & $\begin{array}{c}\text { G2/M } \\
(\%)\end{array}$ \\
\hline P5 & $0.6 \pm 0.7$ & $52.0 \pm 3.5$ & $32.0 \pm 4.2$ & $16.1 \pm 0.7$ \\
P1(0.5) & $0.3 \pm 0.5$ & $54.1 \pm 1.2$ & $27.2 \pm 0.3$ & $18.6 \pm 1.2$
\end{tabular}

Fig. 1D

$\mathrm{CLX}[\mu \mathrm{M}]$

0

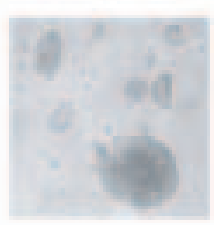

5

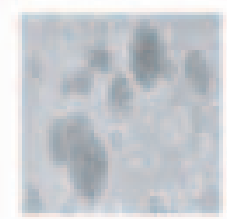

10

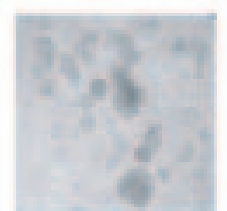

20

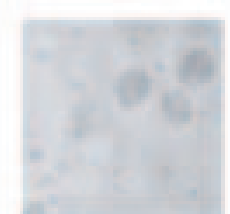

\begin{tabular}{|c|c|c|}
\hline$C L X(1, M)$ & $\begin{array}{c}\text { Colony number } \\
\text { (colomy count plate) }\end{array}$ & Coleny sice $\left(y^{2}\right)$ \\
\hline 0 & $101 \pm 3.6$ & $60 \pm 4.5$ \\
\hline 2.5 & $97 \pm 5.1$ & $55 \pm 4.9$ \\
\hline 6 & $89 \pm 4.7$ & $40 \pm 3.2$ \\
\hline 10 & $50 \pm 32^{\circ}$ & $20 \pm 3.1 *$ \\
\hline 20 & $35+6.1^{*}$ & $18+3.9^{\circ}$ \\
\hline
\end{tabular}

R. Mazzanti Figure 1 


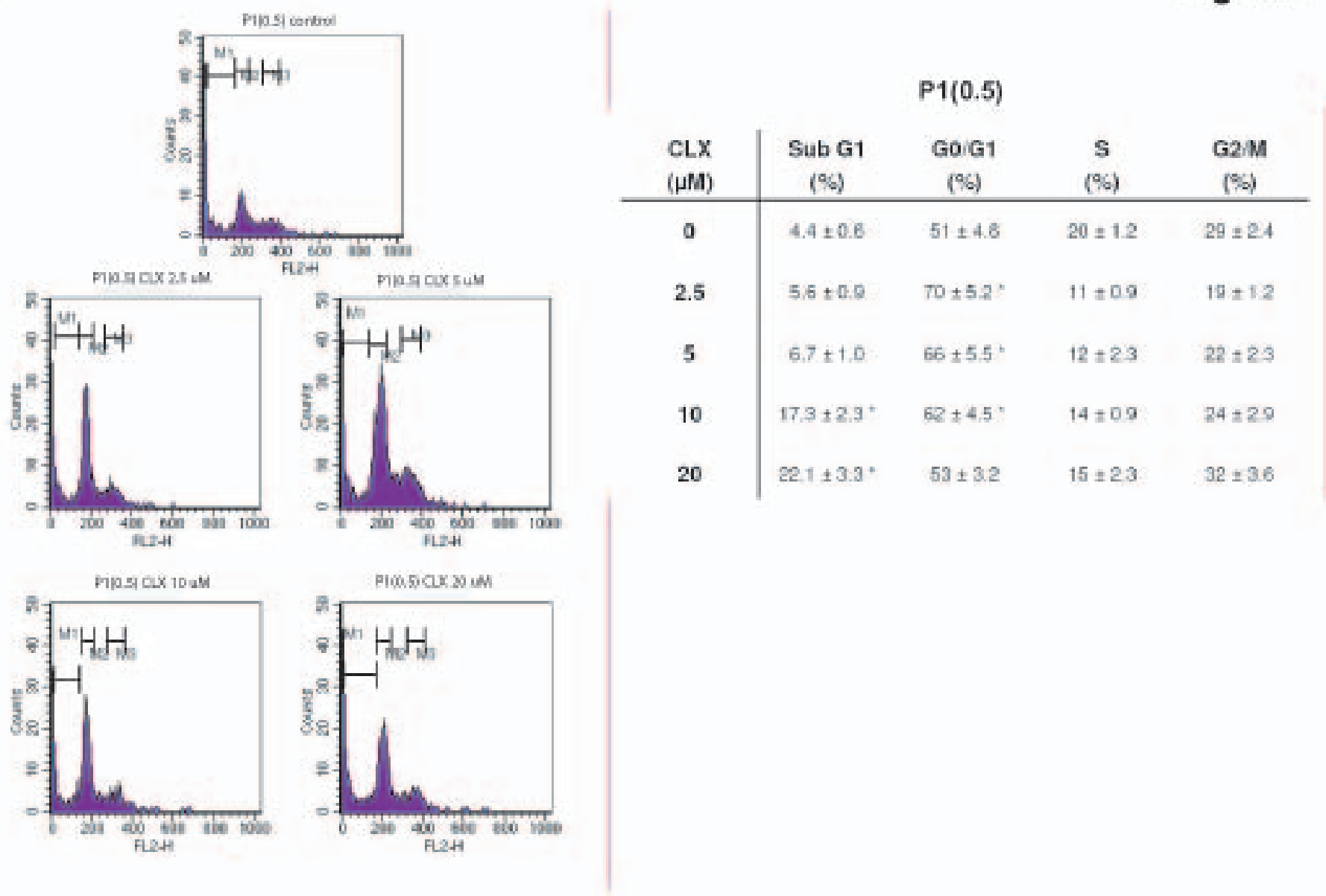

Fig. 2C

P5

\begin{tabular}{c|cccc}
$\begin{array}{c}\text { CLX } \\
(\mathbf{M})\end{array}$ & $\begin{array}{c}\text { Sub G1 } \\
(\%)\end{array}$ & $\begin{array}{c}\text { G0/G1 } \\
(\%)\end{array}$ & $\begin{array}{c}\text { S } \\
(\%)\end{array}$ & $\begin{array}{c}\text { G2/M } \\
(\%)\end{array}$ \\
\hline $\mathbf{0}$ & $0.1 \pm 0.1$ & $57.7 \pm 0.2$ & $34.1 \pm 0.4$ & $8.2 \pm 0.6$ \\
$\mathbf{2 . 5}$ & $1.1 \pm 1.1$ & $57.8 \pm 1.0$ & $34.3 \pm 1.3$ & $7.9 \pm 0.8$ \\
$\mathbf{5}$ & $0.67 \pm 0.97$ & $56.7 \pm 0.9$ & $35.16 \pm 0.22$ & $8.19 \pm 0.63$ \\
$\mathbf{1 0}$ & $1.4 \pm 1.0$ & $58.0 \pm 0.97$ & $33.3 \pm 0.8$ & $8.68 \pm 0.35$ \\
$\mathbf{2 0}$ & $0.7 \pm 0.7$ & $57.5 \pm 1.7$ & $34.7 \pm 1.7$ & $7.7 \pm 0.7$
\end{tabular}


Fig. 4A

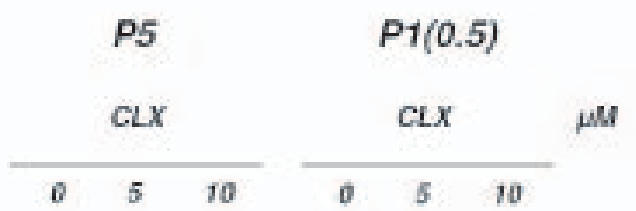

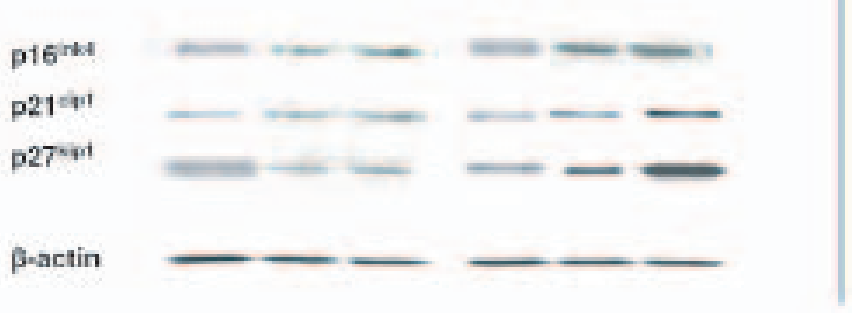

Fig. 4B

P5

CT

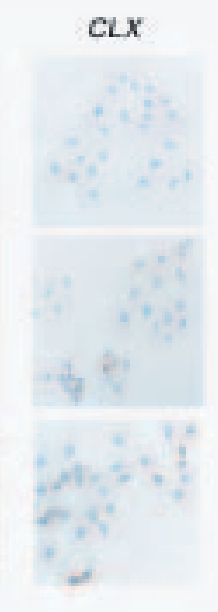

P1(0.5)

Cr

proned

p21하

p27ipt
Fig. 4C

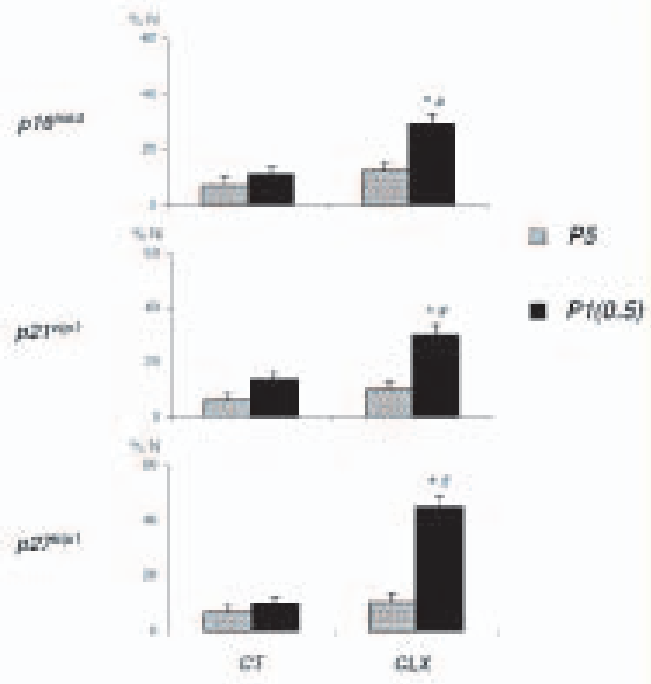

Fig. 4D

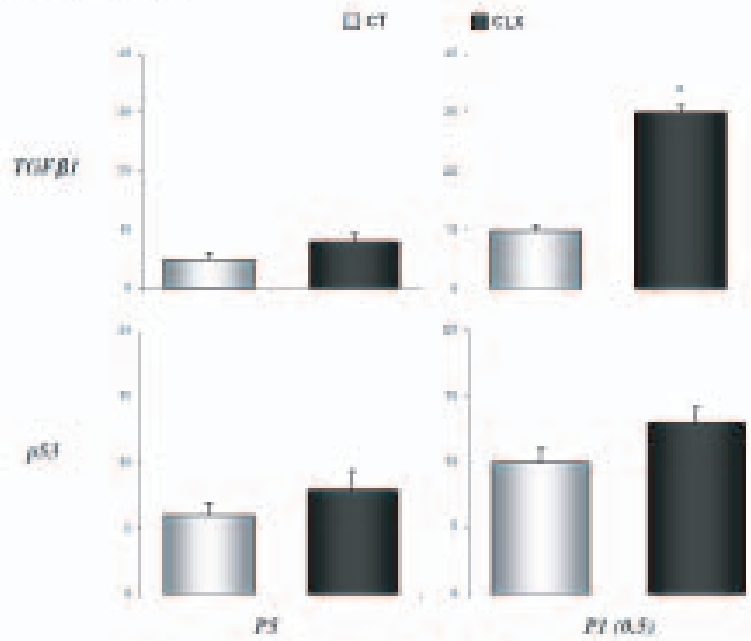


Fig. 5A

\begin{tabular}{|c|c|c|c|c|}
\hline & P5 & \multicolumn{2}{|c|}{$P 1(0.5)$} & \\
\hline & CT CLX & $C T$ & $C L X$ & \\
\hline Cycl D & -- & - & - & $54 \mathrm{kDa}$ \\
\hline Cycl E & $=$ & - & $=0$ & $51 \mathrm{kDa}$ \\
\hline$p R b$ & $-\square$ & - & - & $55 \mathrm{kDa}$ \\
\hline$E 2 F$ & -- & - & - & $56 \mathrm{kDa}$ \\
\hline ERK & $\omega$ & $=$ & $1=0$ & $44 \mathrm{kDa}$ \\
\hline MET & $\cdots \cdots$ & - & - & $145 \mathrm{kDa}$ \\
\hline$\beta$-actin & $-\square$ & & - & $42 \mathrm{kDa}$ \\
\hline
\end{tabular}

Fig. 5B

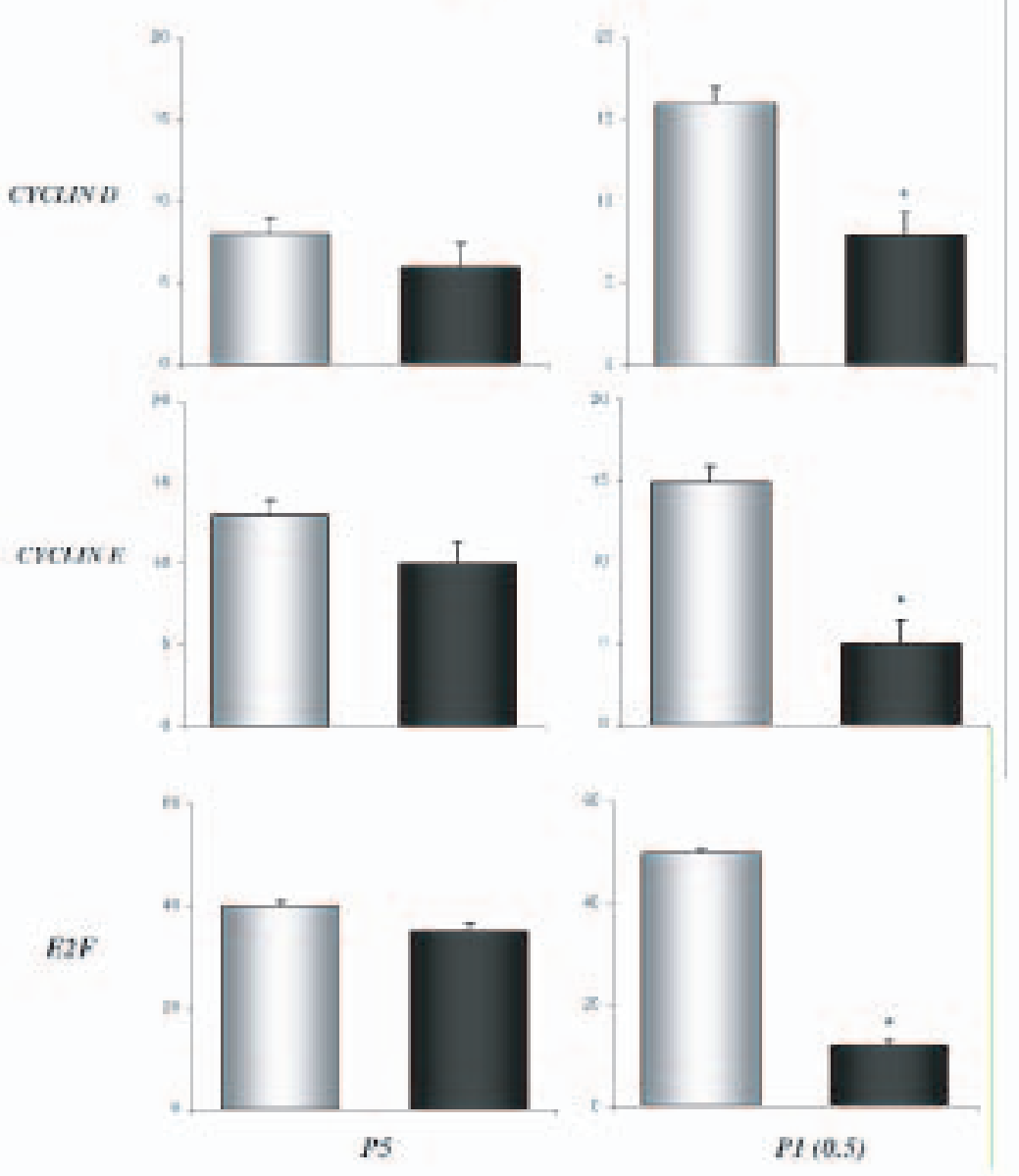

R. Mazzanti Figure 5 
Fig. $6 \mathrm{~A}$

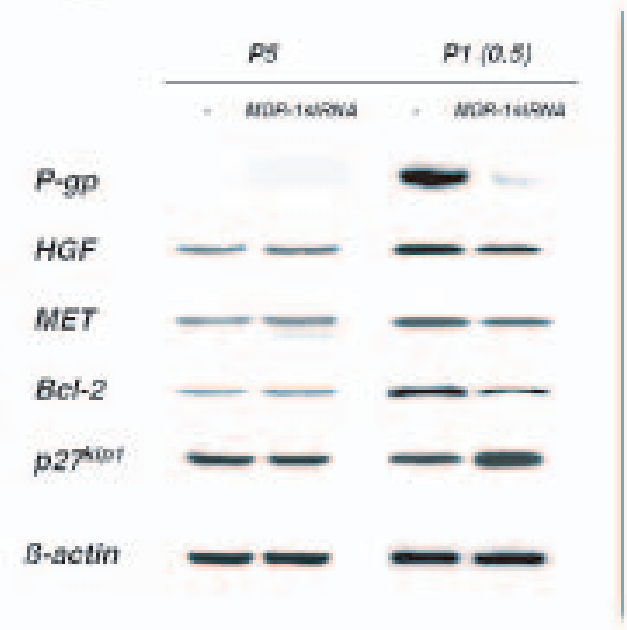

Fig. 6B

CT

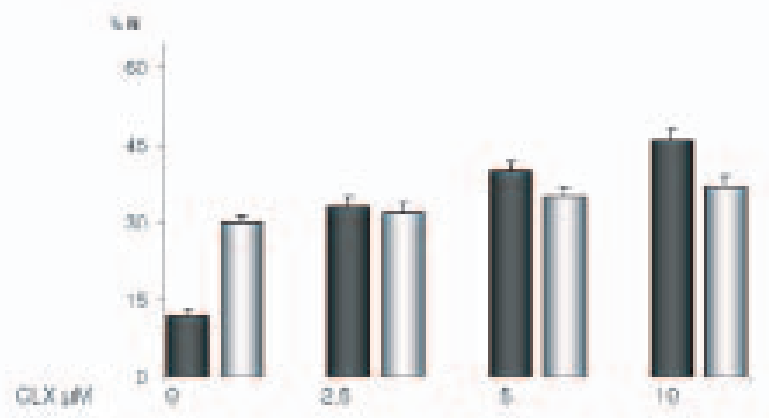

MQRINFNe

Fig. 6C

$C T$

MORI xiRNA

Cix $5 \mathrm{pm}$

CXX 5pM + MOR1 xiRNA
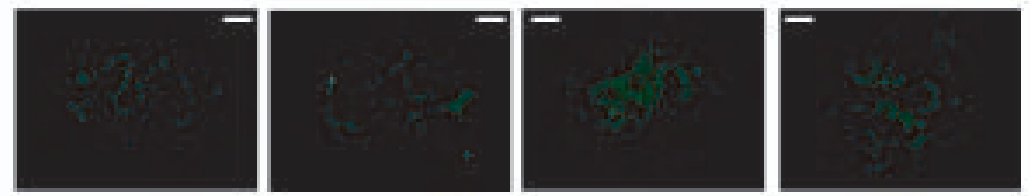

P1 (0.5)
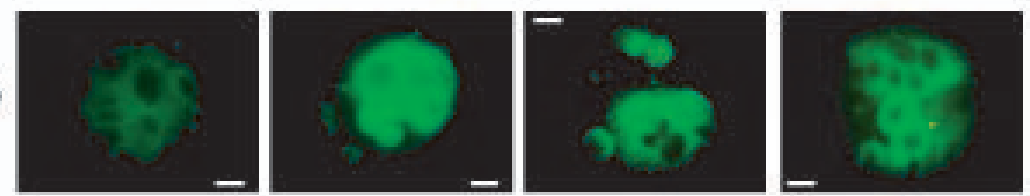

Fig. 6D

\begin{tabular}{|c|c|c|c|c|c|c|c|c|}
\hline \multirow[b]{3}{*}{ 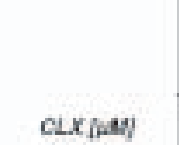 } & \multicolumn{2}{|c|}{ MOAFT-SiRVA } & \multicolumn{2}{|c|}{ MaPT-SiANA } & \multicolumn{2}{|c|}{ MEFT-SieNA } & \multicolumn{2}{|c|}{ MOAT-sieNA } \\
\hline & * & + & 4 & + & . & + & - & + \\
\hline & \multicolumn{2}{|c|}{ o } & \multicolumn{2}{|c|}{2.5} & \multicolumn{2}{|c|}{5} & \multicolumn{2}{|c|}{10} \\
\hline sub or poak ( $(\$)$ ) & $4.2+12$ & $4 . a+0,0$ & $53+22$ & $5 \leq+2.0$ & 6. $2+2.2$ & $5.1+23$ & $15.0+4.2$ & $65+32^{\circ}$ \\
\hline coctir colls (ts) & 4632 & 49283 & $72=10$ & $51 \geqslant 25$ & 6aes 6 & $47+5.5$ & $54=62$ & $4642^{*}$ \\
\hline
\end{tabular}

R.Mazzanti Figure 6 


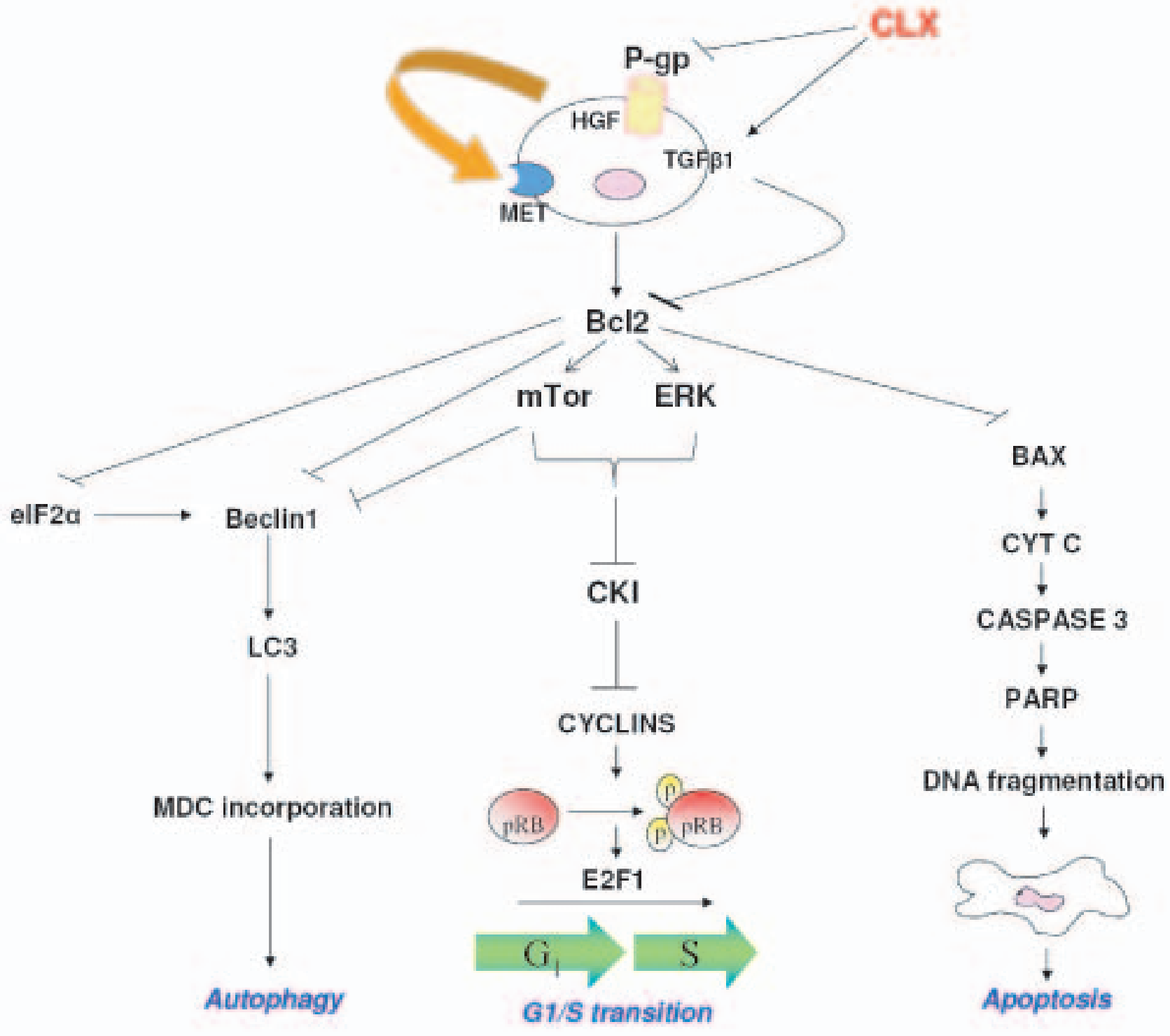

